\title{
THE IMPLEMENTATION OF WTO DISPUTE SETTLEMENT DECISIONS IN BRAZIL: A CONSTITUCIONAL APROACH
}

\author{
A IMPLEMENTAÇAO DAS DECISÕES DO SISTEMA DE SOLUÇÃO DE CONTROVÉRSIAS \\ DA OMC NO BRASIL: UMA ANÁLISE CONSTITUCIONAL
}

\section{Camilla Capucio}

\begin{abstract}
Lecturer in International Law at the Centro Universitário UNA (Brazil) and Universidade FUMEC, and also a researcher at the USP Research Center on International Courts and Tribunals (NETI-USP, Núcleo de Estudos em Tribunais Internacionais). She holds a PhD degree in International Law from University of São Paulo (USP) and a Master's degree in International Law from Federal University of Minas Gerais (UFMG). She acted as a consultant for UNDP East Timor and is a former overseas student at Università degli Studi di Bologna (UNIBO). She is also a member of Brazilian Academy of International Law and a lawyer in Brazil. E-mail: prof.camillacapucio@gmail.com
\end{abstract}

Recebido em: 08/12/2021

Aprovado em: 13/04/2021

\begin{abstract}
This paper discusses the relation between the Brazilian Constitution and the WTO Dispute Settlement System by highlighting the existing challenges between the two and focusing on possible measures for the procedural implementation of these decisions, which emanated from an adjudicatory system of dispute resolution. Although the selection of the implementation measure is a sensible political choice that impacts a wide spectrum of different interest groups in diverse ways, from a constitutional point of view, the Brazilian government shall carry out the selecting process with publicity and transparency, enabling interest groups and agents to present their arguments regarding the possible implementation paths, connecting state governance structures to stakeholders, and by allowing the collective and legitimate construction of public interest.
\end{abstract}

Keywords: WTO; dispute settlement system; implementation process; Brazilian Constitution; transparency; accountability

RESUMO: Este artigo discute a relação entre a Constituição brasileira e o Sistema de Solução de Controvérsias da OMC, destacando os desafios existentes e enfocando as possíveis medidas para a implementação processual dessas decisões, emanadas de um sistema adjudicatório. Embora a seleção da medida de implementação seja uma escolha política sensata que impacta um amplo espectro de diferentes grupos de interesse de diversas formas, do ponto de vista constitucional, o governo brasileiro deve dar publicidade e transparência ao processo de seleção, possibilitando que os grupos de interesse e os agentes apresentem os seus argumentos sobre as possíveis vias de implementação e ligação das estruturas de governança do Estado aos stakeholders, permitindo a construção coletiva e legítima do interesse público.

Palavras-chave: OMC; sistema de solução de controvérsias; processo de implementação; Constituição brasileira; transparência; responsabilidade 
SUMÁRIO: Introduction: Distinctive features of wto dispute settlement decisions. 1 Variables impacting the implementations of wto dispute settlement decisions and member's discretionarity. 2 Implementation process in Brazil: Problems and chalenges. 3 Discretionarity in this subject from a constitutional point of view. 4 Constitutional principles and its applicability to implement decisions. Final considerations: Proposals for ensuring constitutionality of implementation. Bibliographic references.

\section{INTRODUCTION: DISTINCTIVE FEATURES OF WTO DISPUTE SETTLEMENT DECISIONS}

As a unique dispute settlement system that stems from the evolution of international commercial relations since GATT, the WTO dispute settlement system does not fit into the classic configuration of international tribunals (MENEZES, 2013).

Among the specificities of the WTO's dispute settlement system in contrast to other dispute settlement adjudicatory procedures in international law, we may mention: (i) the relationship between the adjudicatory bodies and the DSB in dispute resolution; (i) the strong presence of the negotiation aspect in the procedure, be it at the consultations stage or during other stages of the procedure; (iii) and the "open" character of the resulting decisions of this mechanism, leaving a "discretion space" to be completed by the implementing member.

WTO dispute settlement is composed by adjudicatory (panels and Appellate Body) and political (Dispute Settlement Body) instances (MAVROIDIS, 2008). Hence, the legality of the dispute settlement procedure in the WTO "is part of a broader context, one of diplomatic nature." (LAFER, 1998, p. 749). With regard to its components, DSB is an emanation, an "alter ego" of the WTO General Council (VAN DER BOSSCHE, ZDOUC, 3013, p. 206). However, in order to properly understand the legal nature of the decisions, it is necessary to remember that the most relevant decisions are adopted trough negative consensus or reverse consensus (CROOME, 1998). 1 In that sense, doctrine has interpreted that the reverse consensus rule, in practice, renders the adoption of the adjudicative bodies reports - as well other relevant decisions - "quasiautomatic"(PETERSMANN, 1997, p. 179) or automatic (LAFER, 1998; CAMERON; GREY, 2001).

A situation often observed in many cases is that at least one member of DSB - which will be beneficiated by the position explicitated by the report, beholds substantial interest in the approval of the report, being unlikely to build that consensus to not adopt the reports and therefore transform it in a decision. VAN DEN BOSSCHE and ZDOUC (2013, p. 208) clearly explain this relevant understanding:

As a result of the fact that the DSB takes the core dispute settlement decisions referred to above by reverse consensus, the DSB's impact and influence over consultations and adjudication by panels and the Appellate Body in specific disputes is very limited. The involvement of the DSB is, to a large extent, a legacy of the past in which trade dispute settlement was more diplomatic and political than judicial in nature. Nevertheless, the involvement of the DSB in each major step of a dispute fullfils three useful purposes: (1) it keeps all WTO Members directly informed of the WTO dispute settlement; (2) it ensures multilateral surveillance of DSB recommendations and rulings, thereby exerting pressure on the offending

1 This negative consensus is embodied in the reversal of the consensus rule expressed in Article 2.4 of DSU, that is, it is considered that the DSB has made a decision, unless there is consensus to not take the decision. This is the way decisions such as the establishment of a panel, adoption of panels and Appellate Body Reports and authorization to retaliate are taken. 
party to comply; and (3) it gives WTO members a designated political forum in which issues arising from the use of the dispute settlement system can be debated.

DSB works, therefore, as an instance from which a decision emanates; yet that is emanated as a result of the procedure developed in the dispute settlement system of the WTO as a whole, and therefore its performance does not nullify the legality of the adjudicative system bodies' reports. On the other hand, it is the approval of the reports, even under the rule of negative consensus, which formally grants these documents the legal effects of an international adjudicatory decision.

It should be noted that the relation between DSB and panels and the Appelate Body remains as a historical aspect of the transition from GATT to WTO. The existence of the control more theoretical than practical - from DSB over the decisions made by adjudicative bodies, therefore, does not have the power to hinder the recognition of the adjudicatory nature of the WTO Dispute Settlement System. As stressed by ABI-SABB (2010, p. 13):

The Appellate body thus came into being as part of an Organization whose pervasive atmosphere, lingering from the GATT era, is encapsulated in the mantra that "this is a member-driven organization", and the general feeling that it is the members themselves that take all the final decisions. It had for mandate to interpret and apply very detailed treaty provisions, shoddily drafted, with the injunction that its rulings "cannot add to or diminish the rights and obligations provided in" these treaties; and with the political organs and the member states closely watching (not to say looking over its shoulder) how it interprets and applies them. But at the same time, the Appellate Body had to act with the necessary degree of independence requisite for the exercise of the international judicial function.

Therefore, to recognize the WTO Dispute Settlement System as an adjudicative system is to reaffirm that it was established to resolve disputes on the basis of rules, following the procedures previously set by the DSU, enrolled by independent bodies, and resulting in a binding decision to members in dispute (ROMANO, 2001).

According to this line of interpretation, some of the characteristics that are relevant to the WTO dispute settlement decisions entail (i) legality, (ii) bindingness and (iii) undeterminity (open character of the commands of the decisions, which are undetermined but determinable) (JACKSON, 2004). Decisions made by the dispute settlement system of the WTO are thus expressed as results commands in that they require that the measure recognized as in disconformity be brought in conformity to multilateral obligations. The choice of means by which the result expected is achieved is to be determined by the member, in its discretionary space.

Once a report is adopted, the implementation phase of the decisions is inaugurated and Article 21.1 of the DSU requires "prompt compliance" of the recommendations and decisions made by the DSB, which may be achieved by means of (i) withdrawal/revocation of the measure; or (ii) modification of the measure, in its part containing the violation recognized by the report adopted. 23

2 "[T] he non-conforming measure is to be brought into a state of conformity with specified treaty provisions either by withdrawing such measure completely, or by modifying it by excising or correcting the offending portion of the measure involved. Where the non-conforming measure is a statute, a repealing or amendatory statute is commonly needed. Where the measure involved is an administrative regulation, a new statute may or may not be necessary, but a repealing or amendatory regulation is commonly required. It thus appears that the concept of compliance or implementation prescribed in the DSU is a technical concept with a specific content: The withdrawal or modification of a measure, or part of a measure, the establishment or application thereof by a Member of the WTO constituted the violation of a provision of a covered agreement [...]" WTO. Award of the Arbitrator, Argentina - Measures Affecting the Export of Bovine Hides and Import of Finished Leather (Arbitration under Article 21.3(c) of the DSU), WT/DS155/10, 31 Aug 2001. para(s). 40-41.

3 " [A] Member whose measure has been found to be inconsistent with the covered agreements may generally

Revista de Direito Brasileira | Florianópolis, SC | v. 28 | n. 11 | p.284-299 | Jan./Abr. 2021 
It is important to highlight, at an early stage of this paper, that the recent crisis of the Appellate body, considered by some to be the definitive end of the WTO dispute settlement system (BROWN; KEYNES, 2020), does not diminish, in our opinion, the relevance of this system (HOEKMAN; MAVROIDIS, 2020; PETERSMANN, 2020) or of the discussions that this work intends to instigate. Cases continue to be initiated 4 and adjudicated within the existing framework, and the challenges to achieving a transparent and constitutionally oriented implementation of DSB decisions in Brazil remains an open subject.

\section{VARIABLES IMPACTING THE IMPLEMENTATIONS OF WTO DISPUTE SETTLEMENT DECISIONS AND MEMBER'S DISCRETIONARITY}

Implementation of the decisions involves many variables. These relate not only to the nature of the measure that is questioned, but mainly to the specificities of the domestic legal systems of member states. The complexity of the implementation, therefore, increases in the extent that each national legal system has a unique arrangement between powers and bodies involved in the various themes which - albeit elevated to international standardization - were classically in the scope of action of national institutions.

Under the criteria of subjective competence of the measure, we can see: (i) measures emanated from executive bodies; (ii) measures emanating from legislative bodies; and (iii) measures emanating from judicial bodies. Acts of the three branches are attributable to the States, and therefore entail international responsibility. ${ }^{5}$ Therefore, if the measures in violation of multilateral rules may emanate from organs of the three branches, it is reasonable to assume that the implementation may require measures taken by all these powers. ${ }^{7}$

It is acknowledged that the "simplest" mode of compliance usually occurs when implementation requires an action by the Executive branch, in the exercise of its function of management and definition of policies based on its weighting on the situation and state interests. Implementation measures involving the legislative branch are, as a rule, more complex and time consuming, since these are actions that require modification of a strict sense legislation, and this difficulty can stem from several factors. In addition to the procedures and deadlines regularly required for legislative processes, there may be a political composition of legislative bodies that is not necessarily in line with the party that exercises power in the executive branch, or a perception

choose between two courses of action: withdrawal of the measure; or modification of the measure by remedial action. While withdrawal may be the preferred option to secure "prompt compliance", a Member may, where withdrawal is deemed impracticable, choose to modify the measure, provided that this is done in the shortest time possible, and that such modification is permissible under the DSB's recommendations and rulings." WTO. Award of the Arbitrator, Japan - Countervailing Duties on Dynamic Random Access Memories from Korea (Arbitration under Article 21.3(c) of the DSU). WT/DS336/16, 5 May 2008. para. 37.

4 From January 2019 to March 2021, 26 cases were filed in the WTO dispute settlement system.

5 "[...] the United States, of course, carries responsibility for actions of both the executive and legislative departments of government." WTO. Appellate Body Report, United States - Standards for Reformulated and Conventional Gasoline. WT/DS2/AB/R, 29 April 1996. p. 28.

6 "The United States, like all other Members of the WTO and of the general community of states, bears responsibility for acts of all its departments of government, including its judiciary.” WTO. Appellate Body Report, United States - Import Prohibition of Certain Shrimp and Shrimp Products. WT/DS58/AB/R, 22 Oct. 2001 . para. 173.

7 "We note that a WTO Member "bears responsibility for acts of all its departments of government, including its judiciary." This is supported by Article 18.4 of the Anti-Dumping Agreement, Article XVI:4 of the WTO Agreement, and Article 27 of the Vienna Convention. The judiciary is a state organ and even if an act or omission derives from a WTO Member's judiciary, it is nevertheless still attributable to that WTO Member. Thus, the United States cannot seek to avoid the obligation to comply with the DSB's recommendations and rulings within the reasonable period of time, by relying on the timing of liquidation being "controlled by the independent judiciary" WTO. Appellate Body Report, United States - Measures Relating to Zeroing and Sunset Reviews (Recourse to Article 21.5 of the DSU by Japan). WT/DS322/AB/RW, 29 Aug. 2008. para. 182.

Revista de Direito Brasileira | Florianópolis, SC | v. 28 | n. 11 | p.284-299 | Jan./Abr. 2021 
by parliamentarians that the modification required by the DSB's decision is not relevant or appropriate (DAVEY, 2005).

Implementing measures with the participation of the judiciary are not common, but cannot be discarded from the systematic of implementation by WTO members. In the case entitled Brazil: Measures Affecting Imports of Retreaded Tyres, 8 for example, the use of a Arguição de descumprimento de preceito fundamental (literally translated to claims of non-compliance with a fundamental precept - ADPF) - a kind of judicial review of constitutionality action as a remedy present in Brazilian Constitution - was essential to enable compliance without revoking the measure, which was legitimate in substance.

Therefore, implementation may involve combined and isolated measures that may arise from (a) the executive branch; (b) the legislative branch; and (c) the judicial branch. Such measures may have administrative, legislative or jurisdictional nature.

Regarding the criteria of the extent of inconsistency, measures can be classified as: (i) single or specific measures (with respect to a specific act or identifiable and distinguishable products) or (ii) general applicability measures (which concern procedures and methodologies). ${ }^{9}$ Commensurately, corresponding implementation measures tend to track the amplitude of scope of the inconsistent measure, while also being naturally related to the multilateral obligation and its Agreement in case. Thus, implementation may involve combined and isolated measures of (a) specific character or (b) general character.

Additionally, concerning the decision-making and bureaucracy related to the implementation, these can be composed of ad hoc mechanisms or may have parameters provided in a general regulatory framework. An example of a general regulatory framework is the procedure in US law (URRA) to establish consultations with committees of Congress, private sector committees and the public sphere in general prior to defining the way in which the decision of the WTO dispute settlement system will be implemented.

There are other variables that can contribute to the design of the implementation measure. In particular, these include (a) legal and political aspects of the power structure within the State and (b) the polarization of interests involved in disputes and the ability of different groups to influence implementation.

These variables impact the discretionarity that members are granted in order to implement these decisions in many different aspects, in a way that better suits domestic interests and stakeholders (CAPUCIO, 2019).

\section{IMPLEMENTATION PROCESS IN BRAZIL: PROBLEMS AND CHALENGES}

8 "At the oral hearing, Brazil indicated that acts conducted by the Judiciary had to be attributed to the state just as legislative or executive acts. Therefore, the judiciary, like other branches of power, could contribute to achieving compliance with international obligations. Brazil considered the European Communities' focus on the government's ability to control the achievement of the intended objective of proposed implementation acts as "totally misplaced". Brazil argued that the Federal Government could not "ensure" that its intended results would be achieved, irrespective of whether it undertook action through the Legislative or Judiciary in order to implement the recommendations and rulings of the DSB, because both are separate from the Executive. Brazil stated that even though these two powers operate with a different degree of autonomy, there is no difference in the sense that Brazil's Federal Government cannot guarantee a certain outcome either in the National Congress or before the Federal Supreme Court”. WTO. Brazil - Measures Affecting Imports of Retreated Tyres (Arbitration under Article 21.3(c) of the Understanding on Rules and Procedures Governing the Settlement of Disputes). WT/DS332/16, 29 Aug. 2008. para. 65.

9 "Article 23 interdicts, thus, more than action in specific disputes, it also provides discipline for the general process WTO Members must follow when seeking redress of WTO inconsistencies. A violation of the explicit provisions of Article 23 can, therefore, be of two different kinds. It can be caused by (a) by an ad hoc, specific action in a given dispute, or $(b)$ by measures of general applicability, e.g. legislation or regulations, providing for a certain process to be followed which does not, say, include recourse to the DSU dispute settlement system or abide by the rules and procedures of the DSU." WTO. Panel Report, United States - Sections 301310 of the Trade Act of 1974. WT/DS152/R, 22 Dec. 1999. para. 7.46.

Revista de Direito Brasileira | Florianópolis, SC | v. 28 | n. 11 | p.284-299 | Jan./Abr. 2021 
Implementation of the WTO Dispute Settlement System decisions falls under the broader subject of the implementation of decisions made by international tribunals in Brazil. The Brazilian Federal Constitution of 1988 is silent in this regard and existing practice is ambiguous (DALLARI, 2003). Thus, the mandatory basis and enforceability of international adjudicatory decisions is grounded on the respective treaties that are constitutive of international organizations to which they are attached and / or statutes published by International Courts and Tribunals.

In Brazil, however, there is no prevision of a procedure for the implementation of decisions made by any international organizations, therefore, in practice, implementation has occurred in a casuistic way, depending on the peculiarities and uniqueness of the concrete case. Nevertheless, a serious concern arrives given that no formal act is provided to insert a international organization's decision or an adjudicative decision in Brazil, and neither concede publicity to its content, as required for ratified international treaties. This act of formal incorporation, therefore, is related to the respect for constitutional principles of publicity and legality and - at least in what international treaties are concerned - constitutes an essential requirement to its national invocability and applicability (GABSCH, 2010).

Moreover, the inexistence of a formal act to incorporate these decisions to the Brazilian legal order has granted the Executive branch an almost unlimited "freedom" to choose the way to implement them, as it may prevent judiciary bodies from controlling or regarding them as legal sources.

When Brazil was required to implement a decision of the WTO Dispute Settlement System, the implementation occurred in a "diffuse" manner, "through the adoption of internal acts of adequacy of the legislation challenged in the WTO, inspired by the decisions of the DSB, but not necessarily legally grounded in these decisions." (BENJAMIN, 2013, p. 587)

Thus, under a broader perspective, it is clear that the mechanisms available for the implementation of decisions of the DSB in Brazil are regularly internally used remedies whose goal is to promote the modification of illegal or inconvenient acts, 1011 and there are previous procedures to discuss this that can provide legitimacy for the decision-making.

An interesting experience that has served as an inspirational basis for some of the elements of the procedure proposed in the last part of this paper was the path to the implementation of the Brazilian right to retaliate in the United States - Subsidies on Upland Cotton case. Although that was not an implementation of WTO Dispute Settlement Decisions according to the perspective of the implementing member, at that occasion, the Brazilian government made important choices that expressed a more transparent and democratic perspective with respect to domestic agents and diverse interests. 12

Although there is no precise competence expressed to any governmental? body regarding the implementation of these decisions, in practice two ministries stand out when it comes to conducting the relations under the framework of the multilateral trading system, namely the Ministry of Foreign Affairs (Ministério das Relações Exteriores - MRE) and the Ministry of

10 In the case of aircrafts, the decision was implemented through changes in normative acts that emanated from the Executive branch (Central Bank norms) as well as in the law that established the program which was considered inconsistent in terms of the multilateral obligations in its original formulation.

11 The case of retreated tires proved to be exceptional, in that in the exercise of its internal competences, the Judiciary branch was practicing conducts obstructing the realization of the protective purpose of the measure imposed by the Executive branch. Thus, the implementation of the decision of the WTO's Dispute Settlement System involved a need to standardize national court jurisprudence in order to ensure that courts would not allow the importation of retreaded tires prohibited by the Executive.

12 Implementation of the Brazilian "right" to retaliate in this case involved the following aspects that serve as a successful example and as inspiration for the procedure proposed in last part of this paper: (i) institutionalization of the procedure; (ii) publicity of the acts related to this implementation; (iii) public access and possibility to participate in oral hearings or with written documents; and (iv) establishment of a general legal framework for implementation.

Revista de Direito Brasileira | Florianópolis, SC | v. 28 | n. 11 | p.284-299 | Jan./Abr. 2021 
Development, Industry and Foreign Trade (Ministério do Desenvolvimento, Indústria e Comércio Exterior - MDIC). Within these ministries, two institutions stand out: the General Coordination of Litigation (Coordenadoria Geral de Contenciosos - CGC) and the Chamber of Foreign Trade (Câmara de Comércio Exterior - CAMEX).

With specific regard to the decision-making process that relates to the participation of Brazil in the WTO dispute settlement system, CAMEX is formally consulted by the CGC-MRE before taking any significant step. However, in addition to CAMEX's difficulties to perform its functions, or even in light of these difficulties, there is a perception that, in WTO dispute settlement issues, the position of MRE prevails (RAMANZINI JUNIOR, 2012; BENJAMIN, 2013; ARBIX, 2008).

This trend? is not about an undesirability of the management of these decisions by the CGC or the MRE, whose technical knowledge about Brazil's role in the dispute settlement system of the WTO is notable. What scholars highlight is the recognition that, in this theme, the CAMEX is "relegated to the background, submitting the decisions to forums not provided institutionally and not open to participation of civil society." (ARBIX, 2008, p. 666)

Moreover, the longtime primacy of the Executive Branch on the subject of the construction of foreign trade policies (FARIAS, 2012) and the absence of effective participation of the National Congress in Brazil make the bureaucratic apparatus dominate the formulation process of these measures, which is defined with reduced transparency. In fact, even though the development of external relations is a clear responsibility of the Executive, it is a characteristic of democracies to have a form of consultation with the legislative branch (REZEK, 2013).

In this context, the need to develop mechanisms for transparency and institutionalized participation of civil society needs to be highlighted to inform the perception of the public agent on the public interest to be pursued (VEIGA, 2007).

\section{DISCRETIONARITY IN THIS SUBJECT FROM A CONSTITUTIONAL POINT OF VIEW}

The variety of topics submitted to the dispute settlement system of the WTO and, therefore, that may be subject to a measure of implementation shall not be undermined. Thus, in contrast to GATT, WTO includes a thematic diversity in their agreements that requires a careful balance of multiple interests involved in filling the discretionary space given to members for implementation.

Therefore, under the perspective of the WTO dispute settlement system Brazil has discretionarity to choose how to implement its decisions - albeit not in a limitless way - yet under the domestic perspective, this discretionarity to select implementing paths must be filled having the public interest and the constitutional principles of public administration as its unremovable limits (MAURER, 2006). That is, if from the perspective of the multilateral trading system what matters is solely the result, through the lens of the domestic legal system, we should also evaluate the path chosen.

The reason therefor is the fact that the implementation process of WTO Dispute Settlement System decisions in Brazil, along with its respective acts, should be envisioned as a double object. It is simultaneously a measure of Brazilian foreign policy and a measure of public policy; as such, thus it is an administrative latu sensu activity that should be legally and legitimately grounded.

As pointed out by FREITAS (2013, p. 43):

The principle of genuine public interest dictates that, in the event of collision, the legitimate general will must prevail (the "good of all", as specified by Article 3 of the Brazilian Constitution) over the articulated or selfishly partisan will, without 
confusing that volition with the simple will of the state apparatus, nor with the desire of most [...] the very identification of diffuse interest and collective interest is fraught with pitfalls. Therefore, it should be noted that the public interest is intimately correlated with the protection of the dignity of all people and of each. [...] It is the dignity of all that justifies the legitimate and democratic primacy of public interest over particular interests. (authors' translation)

Desite the MRE's undeniable knowledge on the subject, we must remember that the implementation of such a decision at the domestic level - and its potential impact on public policies of different subjects - involves a much wider spectrum of recipients and therefore attention should be given for the development of mechanisms that enhance the participation of different sectors of Brazilian society in order to disclose the various and opposing interests in this situation (SPECIE, 2008).

Thus, the discretionarity of the Executive Branch in the definition of implementation processes and measures, embodied by the conduction of the CGC-MRE, cannot be confused with total freedom of choice, detached from principles of public administration, and public interest that should guide decision-making by public agents.

With regard to the control of public administration, foreign policy is not exempt from it, according to the principles of public administration set out in the chapeau of Article 37 of the Brazilian Constitution, 13 although its implementation requires deeper reflections.

It would be illusory and innocuous to suppose a complete separation between the public interest and the various private interests concerning Brazil's participation in the WTO dispute settlement system, since, by the very nature of commercial disputes, it is natural that a member seeks to defend the position of economically relevant domestic groups.14 However, at the time of the implementation of the decisions, the interest of several domestic economic groups may conflict and other issues other than trade may be involved, such as public health and the environment, hence public agents must consider these complexities to account for the consideration of multiple perspectives (GUERRA: 2012).

It is necessary to comment two different cases on this subject to see how the discretionary space may be strict or broad, and how the public/national interest was illustrated in both of them.

In the case entitled Brazil - Export Financing Programme for Aircraft, one can say that the discretionary space regarding the implementation path was restricted, since by recognizing the inconsistency of one aspect of PROEX, the Brazilian government could choose between the options of (a) extinguishing the subsidies to the sector or (b) modifying the element inconsistent with the multilateral rules, maintaining the subsidies. The Brazilian government opted for the maintenance of the program, given the strategic nature of the sector and even the success symbolism of the national company, which is competitive in the high-tech sector. In this situation, there was no need to question what would be the national interest.

Nevertheless, in the case Brazil - Measures Affecting Imports of Retreaded Tyres, the multiplicity of interests was manifested in a more evident way, with certain polarization between economic agents interested in the import of retreaded tires and sectors of civil society that were legitimately concerned about public health and the protection of the environment.

In the latter case, in spite of the polarization, again there was not an intensive questioning of the definition of public interest to be protected in the implementation of the decision. Given the different nature of the interests that arised, one can recognize a clear predominance of civil society?

13 Brasil, Constituição da República Federativa do Brasil de 1988. “Art. 37. The direct and indirect public administration of any of the powers of the Union, the States, the Federal District and the Cities will abide by the principles of legality, impersonality, morality, publicity and efficiency and also the following: (...)"

14 This entanglement is such that in Brazil, in most cases, the national economic group is the interested party which has borne the financial cost of the demands of filing (SHAFFER; RATTON SANCHEZ; ROSENBERG, 2008)

Revista de Direito Brasileira | Florianópolis, SC | v. 28 | n. 11 | p.284-299 | Jan./Abr. 2021 
as coincident and, in a way, as the actor that reports the primary interests of the Brazilian government with the establishment of the challenged measure.

Precisely due to the fact that the measure of restriction was originally founded on the legitimate interest of protecting public health and the environment, there was consistency in the maintenance of the measure. Therefore, as the protection of the environment and human health can be found in constitutional provisions, the situation offered a limit to the discretionarity in the definition of the measure (BARROSO, 2009).

\section{CONSTITUTIONAL PRINCIPLES AND ITS APPLICABILITY TO IMPLEMENT DECISIONS}

It is relevant to stress the supremacy of public interest as a constitutional axiom, acting both as a guide and as a limit line for discretion (BAPTISTA, 2003). Additionally, the Brazilian constitution enshrines the fundamental right to a good public administration (FREITAS, 2007), as the responsibility of the State towards the society for illegitimate choices - that is, choices made within the discretionary space that disrespect constitutional principles and the true public interest.

Among the constitutional principles, the principle of publicity is of utmost relevance, as it leads to the requirement of transparency, both of which are corollaries of democratic participation. The principle of transparency, established by Immanuel Kant to the classification of "transcendental principle" (LAFER, 1987-1989, p. 110), should permeate "all sectors and all areas of administrative activity" (MEDAUAR, 2011, p. 137) with fundamental importance in the democratic rule of law. Inserted in the conception of democratic rule of law, the principle of publicity is manifested not only in its formal dimension - connected to the disclosure of information - but mostly should be projected in the material aspect of access promotion by all interested in the formulation, implementation and evaluation of administrative activities.

It is the respect for publicity and transparency that gives individuals the ability to control and participate in decision-making, with a view of approximation between state governance structures and individuals in society. They should be noted not only as conditions of legality for administrative activity, but also as commitments to its legitimacy by allowing democratic participation in its decision processes (MOREIRA NETO, 2006, MIRAGEM, 2011).

In their very essence, transparency and publicity are vectors that must also permeate contemporary diplomacy, in order to adjust it according to the concepts of democracy, participation and public interest. As stated by LAFER (1987, p. 109):

Democracy is a form of government that seeks to integrate the two meanings [of public], assuming that the public interest must be? of collective acknowledgement. That is why it has as its rule the public exercise of the common power. Hence the importance of the issue of transparency of power, as a democratic instrument of control 'ex part populi' over government. Transparency of power is correlated with the freedom of opinion and expression, which requires the right to seek, receive and impart information, enshrined in Article XIX of the Universal Declaration of Human Rights of 1948. The objective of this right is to guarantee an equal participation of citizens in public sphere. It has, as a philosophical foundation, the Kantian sapere aude because the public use of reason itself, which entails the illustration and the majority of men, asks an accurate and honest information, available to all, without which there are subjects but not citizens. For this reason, on the work of the Kantian legacy, as the decisions are made in a democracy, the principle of visibility of power is constitutive. It? allows the information without which all cannot form a proper opinion on the management of the common thing to thus exercise its power of participation and control. Hence the conclusion: in a 
democracy publicity is the rule and secrecy is the exception [...] 15 (authors' translation)

However, as highlighted by some studies, there is still a gap between discourse and practice with regard to transparency in Brazilian foreign policy (WAISBICH, CETRA, MARCHEZINI, 2017).

More recently, a new legal freedom was inaugurated with the "Freedom of Information Act" (Act 12.527/2011), as a result of more than two decades of activism and gained strength with the Inter-American Court of Human Rights decision against Brazil in the case of Gomes Lund et al (TSE 2013). Waisbich et al. state that

In this new legal framework, the right of citizens to information means both the right to receive information (through proactive state transparency) and to request information (through passive state transparency), an idea closely related to the concept of citizen oversight. Furthermore, public bodies have a general duty to provide the public with information about their activities, programmes, and public spending (proactive transparency). Hence, the right of access to information not only has great potential to strengthen the transparency of institutions of representative government, but is also an important tool for empowering citizens, by allowing them to participate more actively and effectively in public decisionmaking processes. (WAISBICH, CETRA, MARCHEZINI, 2017, p. 181).

This same research has shown quantitatively the Ministry of Foreign Affairs' practice of denying access to information, often based on secrecy exemptions in the FOI Act, but constructing the exceptions in a broad and unclear way, that virtually ended up exempting foreign relations from the general transparency rule. The authors conclude:

(...) Itamaraty needs to start understanding the FOI Act as a means of improving its public management. Requests for information under the FOI Act can provide the ministry with indications of which foreign policy issues interest the public, and of gaps in its management of information, which is central to its own policy cycle. (WAISBICH, CETRA, MARCHEZINI, 2017, p. 199).

Although transparency policies require certain conditions to be effective (CUNHA FILHO, 2017; CUNHA FILHO, 2019), their very existence should not be challenged in what concerns diplomacy and foreign policy. Last, but not least, considering transparency as an essential right (RIBEIRO, 2018), there is no room for a democratic paradigm without the acknowledgment of its role in the affirmation of the rule of law (RIBEIRO, 2018).

As we can see, the necessity of "public exercise of common power" demands a different approach to the implementation of WTO dispute settlement decisions in Brazil (DALLARI, 1994).

Furthermore, the 1988 Federal Constitution expressed its commitment to the peaceful settlement of disputes 16 and thus to international rule of law. 17 If on the one hand the Brazilian

15 Authors translation.

16 Brasil, Constituição da República Federativa do Brasil de 1988. Preamble: "We, representatives of the Brazilian people, gathered in the National Constituent Assembly to institute a democratic state, to ensure the exercise of social and individual rights, liberty, security, well-being, development, equality and justice as supreme values of a fraternal, pluralistic and unprejudiced society founded on social harmony and committed, internally and internationally, to the peaceful settlement of disputes, promulgate, under the protection of God, this Constitution of the Federative Republic of Brazil". (authors translation)

17 Brasil, Constituição da República Federativa do Brasil de 1988. Article 4: "The Federative Republic of Brazil is governed in its international relations by the following principles: I - national independence; II - prevalence of human

Revista de Direito Brasileira | Florianópolis, SC | v. 28 | n. 11 | p.284-299 | Jan./Abr. 2021 
Federal Constitution is silent in international matters and with regard to this specific subject, on the other the Brazilian Charter establishes a performance program for its organs and agents, through ideologically oriented objectives and general principles.

This is the context for understanding the true scope of the principles envisioned by the Brazilian constituent for the conduct of foreign policy in the pursuit of achieving the values of development and democracy, on the domestic front, and the rule of law, peaceful coexistence, international cooperation and the defence of national interest in the external perspective (ALMEIDA, 1987-1989; LAFER, 2005).

The definition of public interest - or of national interest- is a complex task in all state practice areas, given the pluralistic character of contemporary societies. This definition requires reinforced care in the subject under analysis, as it is naturally permeable to private interests, which, however, enjoy different powers of influence. Although the public interest may coincide with particular interests, this reinforced attention to identify the first one can be achieved through the institutionalization of consultation mechanisms open to the different economic and social groups involved.

\section{FINAL CONSIDERATIONS: PROPOSALS FOR ENSURING CONSTITUTIONALITY OF IMPLEMENTATION}

As a result of the discussions held throughout the paper, we believe it is urgent to establish a legal framework to increase transparency and predictability in defining the manner to implement decisions of the WTO Dispute Settlement System in Brazil. This framework would not stifle the necessary space of manoeuvre granted to the Executive branch in the construction of continuity between policies; instead, it would allow a democratic progress in filling this space, by promoting greater transparency, legitimacy and control of the organs of the Brazilian government.

The existing model of relationship between economic groups and the de facto bodies responsible for the decisions related to Brazil's participation in the WTO dispute settlement system, allied to the informal character of the concrete participation of these sectors, tends to favour more institutionalized and dominant demands.

These demands are better organized; still, they do not necessarily reflect all shades of legitimate interests to be protected by the Brazilian government and are not necessarily identified with the public interest, which should be the guide in decision-making in public administration (CAPUCIO, 2020).

The perception of the public interest from the diversity of interests that are expressed within the Brazilian State may not be so clear or polarized, given the complexity of the themes influenced by the multilateral trading system. Such complexity has not yet manifested itself intensely in both cases requiring an implementation measure of Brazil. Yet, one cannot restrict the possibility of future claims against the country in the WTO managing diverging interests at the time of implementation.

Furthermore, it is not possible to state that all the measures taken by the Brazilian government - and by any government in the so-called "real world" - always reflects a democratically constructed consensus or necessarily promote the public interest of its respective society. It is well known that the public interest is not characterized as such by being emanated from an administrative authority, since many times this authority acts to dismiss this interest (MELLO, 2014).

Thus, when such measures are challenged under the WTO Dispute Settlement System, and when the moment to implementat its decision arrives, the choice of the path for this

rights; III - self-determination; IV - non-intervention; V - equality among States; VI - defense of peace; VII - peaceful settlement of conflicts; VIII - repudiation of terrorism and racism; IX - cooperation among peoples for the progress of humanity; and X - granting of political asylum".

Revista de Direito Brasileira | Florianópolis, SC | v. 28 | n. 11 | p.284-299 | Jan./Abr. 2021 
implementation can serve as an opportunity to discuss the convenience and opportunity of the original measure.

Therefore, even when the concrete specifics of the decision of the WTO Dispute Settlement System allow the maintenance of the measure with adjustments, this maintenance would not necessarily be the best choice under the perspective of public interest to the Brazilian society (CAPUCIO, 2020).

Implementation of decisions of the WTO Dispute Settlement System offers a unique opportunity to democratic States to problematize, discuss and build their measures in light of the participation of private sector and civil society. Moreover, even within the private sector, there is a natural conflict between visions, since the economic agents are affected very differently by an implementation path that may benefit some and harm others, whereas the choice of another implementation path could reverse these results.

The differences are natural, beneficial and even essential to a democracy. And the Executive branch is responsible for the very balance of these differences in decision-making and in defining governmental strategies, considering that the intent of this regulatory framework is not to propose to replace the role of decision-making bodies in the implementation phase. What is pursued, nevertheless, is an implementation that occurs in a more transparent, participatory manner, and closer to the Brazilian society.

From this reflection, it is possible to foreseen multiple benefits of establishing a general legal framework for the implementation of decisions. The first advantage, thus, would be to increase its predictability and legal certainty. In addition, the legislative provisions of institutionalized manifestation and participation by stakeholders gives legitimacy to the implementation measure chosen by Brazilian government. It is not about ensuring that all groups will have their interests upheld by the procedure, which would be impossible, but to ensure that such perspectives will be considered in the arbitration of the decision guided by the public interest.

In this context, we propose the creation of a general legal framework for the implementation of the WTO dispute settlement decisions, resolving ambiguities and balancing the flexibility that must necessarily exist to ensure transparency and the possibility of engaging stakeholders.

Such legislation should outline a procedure for the definition of the implementation measure that would be its ultimate goal. By predicting an ordered set of steps, transparency would be increased and the participation of civil society and economic groups with an interest in implementation could be institutionalized, and means of cooperation between the public authorities could likewise be formalized.

In general, we envisage that this procedure might include some acts, such as:

(a) an official publication of the decision of the WTO Dispute Settlement System (decision made by the DSB and, accordingly, the panel report and/or the Appellate Body adopted), by presidential decree;

(b) the creation of a Technical Group under CAMEX, with the participation of relevant ministries to the subject of the decision, representatives of civil society organizations and major economic groups involved in the issue;

(c) Consultation with the MRE's Legal Department, the Attorney General's Office and with the Federal Public Ministry (the latter body in case the implementation in question is a relevant theme);

(d) wide publicity of the opinions expressed by theses bodies and opening of consultations to submit written contributions and public hearings about the decision and possible paths of implementation; 
(e) public discussions on possible ways to implement the decision and the publicity of a report explaining the possible paths of implementing the decision, and potential legal, political and economic consequences envisaged with its respective adoption.

With the adoption of these elements, we believe that a more democratic and inclusive procedure can be drawn regarding the definition of the path to implement WTO Dispute Settlement Decisions in Brazil. Through this procedure, international rule of law and public sphere can meet reinforcing democratic values internationally and domestically.

\section{BIBLIOGRAPHIC REFERENCES}

ABI-SAAB, Georges Abi-saab. The Normalization of International Adjudication: Convergence and Divergencies., vol. 43, p.1-43, 2010-2011.

ALMEIDA, Paulo Roberto de. Relações Internacionais e Interesse Nacional: As Relações Econômicas do Brasil e a Ordem Constitucional. Boletim da Sociedade Brasileira de Direito Internacional, vol . 108, 1987-1989.

ARBIX, Daniel A. Contenciosos brasileiros na OMC: pauta comercial, política e instituições. Contexto Internacional, 2008.

BAPTISTA, Patricia. Transformaçoes do Direito Administrativo. Renovar: Rio de Janeiro, 2003.

BARROSO, Luís Roberto. A Ordem Econômica Constitucional e os Limites à Atuação Estatal no Controle de Preços. In: Temas de Direito Constitucional. Tomo II. Rio de Janeiro: Renovar, 2009.

BENJAMIN, Daniela Arruda. A aplicação interna das decisões do Órgão de Solução Controvérsias da OMC na prática in BENJAMIN, Daniela Arruda (ed.), O Sistema de Solução de Controvérsias da OMC: uma perspectiva brasileira. Brasília: FUNAG, 2013.

BROWN, Chad P., KEYNES, Soumaya. Why Trump Shot the Sheriffs: The End of WTO Dispute Settlement 1.0. Peterson Institute for International Economics, Working Paper .March 2020. Available from < https://www.piie.com/system/files/documents/wp20-4.pdf>. Access on 04 Mar. 2021.

CAMERON, James. Principles of International Law in the WTO Dispute Settlement Body. International and Comparative Law Quarterly, 2001.

CAPUCIO, Camilla. Implementação das decisões do sistema de solução de controvérsias da OMC: experiências, mecanismos e variáveis. Revista da Faculdade de Direito da Universidade São Judas Tadeu, n. 7, p. 45-62, 2019.

CAPUCIO, Camila. O sistema de solução de controvérsias da Organização Mundial do Comércio: implementação e mecanismos nacionais de efetivação. 1. ed. Belo Horizonte: Arraes, 2020. v. 2.

CROOME, John. Reshaping the World Trading System: A history of the Uruguay Round (2nd ed., 1998) <http://www.hse.ru/data/2011/12/05/1271919456/Reshaping\%202_e.pdf> accessed on: 10 jun. 2018. 
CUNHA FILHO, Marcio Camargo. A construção da transparência pública no Brasil: análise da elaboração e implementação da Lei de Acesso à Informação no Executivo Federal (2003-2019). PHD Thesis, Universidade de Brasília, 2019.

CUNHA FILHO, Marcio Camargo. The Right to Information System in Brazil. Verfassung und Recht in Übersee / Law and Politics in Africa, Asia and Latin America Vol. 50, No. 4, Special Issue: The Right to Information, p. 412-434, 2017.

DALLARI, Pedro Bohomoletz de Abreu. Constituição e os Tratados Internacionais. São Paulo: Saraiva, 2003.

DALLARI, Pedro Bohomoletz de Abreu Dallari. Constituição e Relações Exteriores. São Paulo: Saraiva, 1994.

DAVEY, William J. The implementation that demands conduct of Congress has proved especially problematic in the US. In: Implementation in WTO Dispute Settlement: An Introduction to the Problems and Possible Solutions'. RIETI Discussion Paper Series, 2005, n. 05-E-013.

FARIAS, Rogério de Souza. Industriais, Economistas e Diplomatas: O Brasil e as negociações comerciais multilaterais (1946 - 1967). PHD Thesis, Universidade de Brasília, 2012.

FERNANDEZ, Francisco Luiz. Princípio da Juridicidade: O supraprincípio normativo no direito público. Revista de Direito Brasileira, ano 3, vol. 6, 2013.

FREITAS, Juarez. O Controle dos Atos Administrativos e os princípios fundamentais. São Paulo: Malheiros Editores, 2013.

FREITAS, Juarez. Discricionariedade Administrativa e o Direito Fundamental a Boa Administração Pública. Malheiros: São Paulo, 2007.

GABSCH, Rodrigo D'Araujo. Aprovação de tratados internacionais pelo Brasil: possíveis opções para acelerar o seu processo. Brasília: FUNAG, 2010.

GUERRA, Sergio. Discricionariedade Administrativa - Limitações da vinculação legalitária e propostas pós-positivistas. In ARAGAO, Alexandre Santos de; MARQUES NETO, Floriano de Azevedo Marques. Direito Administrativo e seus novos paradigmas. Belo Horizonte: Editora Forum, 2012.

HOEKMAN, Bernard M.; MAVROIDIS, Petros C. To AB or Not to AB? Dispute Settlement in WTO Reform. European University Institute. Robert Schuman Centre for Advanced Studies. Global Governance Programme. EUI Working Paper RSCAS 2020/34. Available from: https://cadmus.eui.eu/bitstream/handle/1814/67008/RSCAS\%202020_34.pdf?sequence=1\&isAll owed=y. Accessed on 05 mar. 2021.

JACKSON, John. International Law Status of WTO Dispute Settlement Reports: Obligation to Comply or Option to Buy Out? American Journal of International Law, vol. 109, 2004.

LAFER, Celso. Diplomacia e Transparência: o Arquivo do Itamaraty. Boletim da Sociedade Brasileira de Direito Internacional, vol. 108, 1987-1989. 
LAFER, Celso. O Sistema de Solução de Controvérsias da Organização Mundial do Comércio in CASELLA, Paulo Borba; MERCADANTE, Araminta de (eds), Guerra comercial ou integração mundial pelo comércio?: a OMC e o Brasil. São Paulo: LTr, 1998.

MAVROIDIS, Petros. Outsourcing of Law? WTO Law as Practiced By WTO Courts. American Journal of International Law, vol. 421, 2008.

MAURER, Hartmut. Direito Administrativo Geral. São Paulo: Manole, 2006.

MEDAUAR, Odete. Direito Administrativo Moderno. São Paulo: Editora RT, 2011.

MENEZES, Wagner. Ordem Global e Transnormatividade. Ijuí: Ed. Unijuí, 2005.

MENEZES, Wagner. Tribunais Internacionais: Jurisdição e Competência. São Paulo: Saraiva, 2013.

MIRAGEM, Bruno. A nova administração pública e o direito administrativo. São Paulo: Revista dos Tribunais, 2011.

MOREIRA NETO, Diogo de Figueiredo. Princípios informativos e interpretativos do direito administrativo, in: MOREIRA NETO, Diogo de Figueiredo, Mutações do Direito Público. Rio de Janeiro: Editora Renovar, 2006.

PETERSMANN, Ernst-Ulrich. Neo-liberal, state-capitalist and ordo-liberal conceptions of world trade: The rise and fall of the WTO dispute settlement system. LAW 2020/16 European University Institute, Department of Law. Available from:

https://cadmus.eui.eu/bitstream/handle/1814/68786/LAW_2020_16.pdf?sequence=1. Accessed on 06 mar. 2021.

PETERSMANN, Ernst-Ulrich. The GATT/WTO Dispute Settlement System: International Law, International Organizations and Dispute Settlement. London: Kluwer Law International, 1997.

RAMANZINI JÚNIOR, Haroldo. O Brasil e as Negociações no Sistema GATT/OMC: Uma Análise da Rodada Uruguai e da Rodada Doha. PHD Thesis, Universidade de São Paulo, 2012.

REZEK, Francisco. Parlamento e Tratados Internacionais: O Modelo Constitucional do Brasil. Revista de Direitos Fundamentais, v. 14, n. 14.1, 2013.

RIBEIRO, José Horácio Halfeld Rezende. Transparency as a Paradigm for Democracy Under the Rule of Law. International Journal of Open Government, Vol 7, p. 55-66. 2018.

ROMANO, Cesare. A Taxonomy of International Rule of Law Institutions. Journal of International Dispute Settlement, vol. 241, 2011.

SHAFFER, Gregory; RATTON SANCHEZ, Michelle; ROSENBERG, Barbara. The Trials of Winning at the WTO: What Lies Behind Brazil's Success. Cornell International Law Journal, vol. 383,2008 . 
SPÉCIE, Priscila. Política Externa e Democracia: Reflexões sobre o acesso à informação na política externa brasileira a partir da inserção da temática ambiental no caso dos pneus entre o Mercosul e a OMC. Master’s Degree Dissertation, Universidade de São Paulo, 2008.

VAN DEN BOSSCHE, Peter; ZDOUC, Werner. The Law and Policy of the World Trade Organization. Cambridge: Cambridge University Press, 2013.

VEIGA, Pedro da Motta. Política Comercial no Brasil: características, condicionantes domésticos e policy-making, in ICONE, FIPE e DFID (Eds) Politicas comerciais comparadas: desempenho e modelos organizacionais. São Paulo: Singular, 2007.

WAISBICH, Laura Trajber; CETRA, Raísa; MARCHEZINI, Joara. The Transparency Frontier in Brazilian Foreign Policy. Contexto internacional, Rio de Janeiro, v. 39, n. 1, p. 179-200, Apr. 2017 . Available from <http://www.scielo.br/scielo.php?script=sci_arttext\&pid=S010285292017000100179\&lng=en\&nrm=iso>. Access on 04 Mar. 2021. 